\title{
Loneliness among Elderly Resident and Non Residents at the Eldery Care Homes in Port Said City: Comparative Study
}

\author{
NAGLAA IBRAHIM MOHAMED GIDA, D.N.Sc.*; REDA IBRAHIM EL-MOWAFY, D.N.Sc.*; \\ NAHED ABDELAZEEM ABDELSLAM, D.N.Sc.* and MAI MAMDOUH MOHAMED BADRAN, M.Sc.** \\ The Department of Family and Community Health Nursing, Faculty of Nursing, Port-Said* and Mansoura** Universities, Egypt
}

\begin{abstract}
Background: Loneliness is a problem for a large portion of elderly people. Many factors affect the elderly; separation or dying of spouse, decrease the level of education or economic status result in loneliness.
\end{abstract}

Aim of Study: Explore the feeling of loneliness among the elderly residents and non- residents at the eldry care homes in Port Said City.

Research Design: A comparative descriptive design was used to conduct this study.

Sample size: The subject of the study compromised all the geriatric people residing in the two governmental eldry care homes in Port Said and Port Fouad (92 elders) and 144 elderly people from the Elderly Health Center in Al-Manakh District in Port Said City.

Material and Methods: The data were collected using a personal structured interview questionnair, Barthel index scale, University of California, Los Angeles loneliness scale (ULCA) and the geriatric depression scale (GDS).

Results: According to the elderly people living at their homes; $(57.6 \%, 29.2 \% \& 13.2 \%)$ of them had low, mild \& high feeling of loneliness respectively while, $(19.6 \%, 45.7 \%$ $\& 34.8 \%$ ) of residents at eldry care homes had (low, mild and high) loneliness respectively. The difference was statistically significant.

Conclusion: The study revealed that residents in the nursing homes significantly had high feeling of loneliness more than elderly people living at their homes. The most important factors that significantly affected the feeling of loneliness were marital status, income, health status and depression.

Recommendation: Encouraging elderly people to participate in social events and increase their social contacts by visiting their family members or friends.

Key Words: Elderly - Eldry care homes - Loneliness - Non residents - Residents.

Correspondence to: Dr. Naglaa Ibrahim Mohamed Gida, The Department of Family and Community Health Nursing, Faculty of Nursing, Port-Said University, Egypt

\section{Introduction}

LONELINESS is undesirable feeling due to a perceived difference between the desired and the achieved level of relationships. Loneliness is a state with feelings of distress, depression and isolation due to a wide emptiness in a one's social and emotional life $[\mathbf{1 , 2}]$.

Old age is a biological fact that has its own qualities, mostly exceed people's control. The old age is divided into three groups; young-old (aged 60-74), middle old (ages 75-84), and oldest-old (above age 85). The population aging is often seen as a success for public health policies and for socioeconomic advancement, on another hand, it becomes a challenge to the society to cope with the ability and health status of old people as well as to their community participation and security. Physical and mental capacities were not only affected by aging but also the change in the elders' participation in the community and the decrease of relationships with others as friends, family members and relatives which resulted in loneliness $[3,4,5]$.

The rate of the elderly people in the world over 60 years between 2015 and 2050 will increase twice from $12 \%$ to $22 \%$. By 2050 , the world's people aged 60 years and above are predicted to be 2 billion, arise from 900 million in 2015. In 2018,125 million people are aged 80 years or older. Up to $50 \%$ of those aged over 60 years are at risk of loneliness and about one third of old people will complain some degree of loneliness at old age [6,7].

Loneliness is a problem for a large portion of the people. Many factors affect the elderly; separation or dying of spouse, decrease level of educa- 
tion or economic status, having chronic illness, poor health, lack of visits by relatives or friends, discontented with the place of living. These factors seriously affect the activities of daily living and social relation leading to loneliness. The dying of a spouse in elderly women is the most disturbing life event they cannot resist [8,9]

There is various physical and mental health problems associated with the feeling of loneliness experienced by the elderly. The most known complications linked to the loneliness are depressi0n, cognitive decline and early death. Chronic loneliness may challenges the individual's feeling of being well and increase the risk of suicide [10] Additionally, loneliness is accompanied with hypertension, disability, cardiovascular disease, cognitive illness and other bad health outcomes that result in increasing the need for hospitalization and leading to increasing health care utilization [11].

The feeling of loneliness among the elderly living in nursing homes was common than among those who living with their families. The decrease of the feeling of loneliness among the elderly residents at nursing homes associates with well mental state. Also, the decrease of the feeling of loneliness among the elderly living in their homes associates with high mental state and increase the ability to endure difficult conditions $[12,13]$

Nurses have an important role in loneliness intervention. Firstly, they identify the elderly people who are at risk for loneliness and understand the factors that lead to loneliness in various setting. Secondly, nurses develop interventions to alleviate the loneliness and treat both emotional and social loneliness. Finally, they evaluate the effect of these interventions. Also, it was proved that nurses can alleviate the feeling of loneliness among the elderly by engage them in daily activities and social events $[14,15,16]$

\section{Significance of the study:}

Several researchers have analyzed the association of loneliness with the old age. The prevalence of feeling of loneliness was $9.9 \%$ in South Africa [17]. In Assuit at Egypt, about $72 \%$ of elderly people had severe 10neliness, while $26 \%$ of them had moderate loneliness [18]

Loneliness is one of the main factors leading to depression, and an important cause of suicide and suicide attempts. Loneliness also can stem from bad experiences as living alone, missing an intimate attachment and changing residence to a nursing home. Although the feeling of loneliness is considered an obvious and growing problem among the elderly people, there weren't any previous studies about loneliness accomplished in Port Said city. So, we decide to conduct this study to assess feeling loneliness among the elderly residents and non residents at the eldry care homes in Port Said City.

Aim of study:

Explore the feeling of loneliness among the elderly residents and non-residents at the eldry care homes in Port Said City.

Objectives of the study:

- Identify the factors affecting loneliness among the elderly residents and non-residents at the eldry care homes in Port Said City.

- Compare the levels of feeling loneliness between the elderly residents and non-residents at the eldry care homes in Port Said City.

\section{Subjects and Methods}

\section{Technical design:}

The technical design for this study includes the research design, setting, subjects, and tools of data collection.

\section{Research design:}

A descriptive study design was used to conduct this study. This cross-sectional analytical study.

\section{Study setting:}

This study was carried out at governmental nursing homes in Port Said City. There were two homes namely; Mabratah Muslims for elderly in Port Said City -eldry care home in Port Foaad and one outpatient clinic namely; Elderly Health Center in Al-Manakh District in Port Said City affiliated to ministry of health because this was the only outpatient clinic for elderly.

Study subjects:

All the geriatric people residing in the two governmental nursing homes in Port Said and Port Fouad (92 elders) and The sample size of the elderlies who attending outpatient Elderly Health Center in Al-Manakh District in Port Said City and living at their homes calculated by using equation of Charan and Biswas [19]

$$
\text { Sample size }=\frac{\mathrm{Z} 1-\alpha / 2 \mathrm{P} 2(1-\mathrm{P})}{\mathrm{D}^{2}}
$$

Z 1-a/2: Percentile of standard normal distribution by confidence level $=1.96$ 
P: Expected proportion in population-based on previous studies' prevalence of loneliness in elderly $=9.9$ according to Phaswana, et al.

D: Absolute error or precision (5\%)

$$
\text { Sample size }=\frac{1.9622 \times 0.099 \times(1-0.099)}{(0.05)^{2}}
$$$$
\begin{aligned}
& =\frac{3.8915 \times 0.099 \times 0.901}{0.0025} \\
& =\frac{0.3426668784}{0.0025} \\
& =137
\end{aligned}
$$

The calculated sample size would be 137 elderly due to the expected non participatory rate $(5 \%)$ the final sample size will be (144) old person.

\section{Total number sample:}

- Residents at nursing homes $=92$ elderly.

- Non-residents $=144$ elderly.

- $($ Residents and non-residents $)=236$ elderly .

Exclusion criteria:

- Under 60 years old.

- Elders refuse participation in the study.

- Elders with mental illness.

Tools for data collection: Four tools were used in data collection:

Tool (I): Eldely structured interview questionnair:

This tool was adopted from Ahmed [33] in the form of simple Arabic language. It consists of:

1- Personal characteristics of the elderly people such as age, sex, marital status, level of education, occupation before retirement, income and living conditions.

2- Health profile of elderly such as medical health history, falling, elders' perception about their health, hearing, vision and using aids.

3- Physical status as hearing, vision and using aids.

4- Social and entertainment activities: Having someone to talk with, hobbies and interests, rate of other's visits to the elderly, relation with persons visiting him.

5- Geriatric homes: Date and decision of admission, acceptance of geriatric home, duration of stay, satisfaction of elderly home, feeling now and at time of admission to the geriatric home.

Tool II: Barthel index scale:

Barthel Index scale was developed by Mahoney \& Barthel [20] in English Language. This scale was translated into Arabic language [21], validated and tested for its reliability ( $r=0.971)$. This scale used to measure performance in activities of daily living (ADL). It consist of 10 questions to assess the person's abilities in the ten items which addressed in the Barthel scale are presence of fecal incontinence, help needed with feeding, walking, dressing or bathing, etc).

\section{Scoring system:}

Each performance item is rated on this scale with a given number of points assigned to each level as following: $0=$ Dependent, $1=$ Needs help, $2=$ Independent. Total scores range from 0 to 20 , evaluated in the following manner: Scores of 0-7 indicate dependent, 8-12 indicate independent with assistance, 13-20 indicate independent.

\section{Tool III: UCLA Loneliness Scale:}

UCLA loneliness scale (version 3) was adopted from Russell in English language designed to measure one's subjective feelings of loneliness as well as feelings of social isolation [22]. It was translated into Arabic language by El Desoky [23], validated and tested for its reliability by Ebraheem, et al. [18]. This scale consists of 20-item such as talking to people, turning to them, feeling alone and close to anyone 2 - Question numbers $(1,5$, $6,9,10,15,16,19,20)$ indicated loneliness when answered negatively. Participants rated each item as the following: 0 ("I often feel this way"), S ("I sometimes feel this way"), R ("I rarely feel this way"), N ("I never feel this way").

\section{Scoring system:}

Scoring: $0=4, S=3, R=2$, and $N=1$. Total score range from low feeling of loneliness $=20<40$, mild feeling of loneliness $=40<60$, high feeling of loneliness $=60<80$.

\section{Tool IV: The Geriatric Depression Scale (GDS):}

A short form GDS was adopted from Sheikh, \& Yesavage [24] in English language and translated into Arabic language, validated and tested for its reliability ( $r=.70$ ) by El Husseini [25]. It consisting of 15 items, 10 indicated the presence of depression when answered positively such as (dropped many of your activities and interests, your situation is hopeless and....), while the rest (question numbers $1,5,7,11,13$ ) indicated depression when answered negatively such as (feel happy most of the time, full of energy and 2 .

\section{Scoring system:}

Participants rated each item as the following: Yes (1) \& N0 (0). Scores of 0-4 are considered normal, 5-8 indicate mild depression; 9-11 indicate 
moderate depression; and 12-15 indicate severe depression.

\section{Pilot study:}

A pilot study was carried out on $10 \%$ (24) of the total sample ( 9 from the eldry care homes and 15 from the outpatient geriatric clinic). It was conducted at the second week of May 2018 to the end of May 2018 to test clarity and feasibility of the tool, also to estimate the proper time to complete the tool and find out any problems that might interfere with the data collection. The pilot study was included in the study because there was no need for modification of the tool.

\section{Field of work:}

- Before beginning collection of the data, agreements of directors of eldry care homes and outpatient center at Port Said City obtained, this step take one week at May 2018.

- The managers of each studied elderly home were informed about the purpose of the study, and then taken their oral consent to conduct the study.

- The study was conducted on 236 elderly using interview technique that was conducted on an individual basis by researcher.

- The data have been collected over a period of three months. The actual field of work carried out from begining of June (2018) to the begining of September (2018). Data collected from the two nursing homes at the first month. Data collected from the outpatient clinic at rest two months.

- Each elderly was individually interviewed using the previously mentioned study tool for 30-40 minutes acc0rding to suitable time.

- Collected data was from 5 to 7 elderly per day. Four day per week from 9 Am to 2 pm. Data were categorized by researcher checked and revised at October 2018 and then data were statistical analyzed at from the beginning of November 2018 to the beginning of mars 2019.

- The present study consumed about 9 months. One month of them for obtaining the official permission, pilot study and test clarity and feasibility of tool. The next three months consumed for data collection while, one month months for data entry and four months for statistical analysis.

\section{Administrative design:}

Before applying the study, an official letter was approved by the dean of the faculty of nursing, Port-Said University; then it was sent to the director of each setting (Elderly Health Center in Al-Manakh District at Port Said City-Mabratah Muslims to care for the elderly in Port Said City-eldry care home in Port Fouad) to obtain permission to conduct the study. An agreement was taken from the director of each elderly place after explaining the aim of the study.

\section{Ethical considerations:}

Explain the aim of the study to the directors of elderly places to take their permission to do this study. Verbal consent was obtained from each participant to participate in the study after explaining the aim of this study and the importance of his/her participation, as well as stressing on confidentiality of the collected information. The process of data collection has not distributed the harmony of the work. All participants had the right to withdraw from the study at any time.

\section{Statistical analysis:}

After data were Collected, they were coded, and transferred into especially designed formats so as to be suitable for computer feeding following data entry checking and verification processes were carried out to avoid any errors during data entry process, frequency analysis, cross tabulation, and manual reversion were used to detect any errors. The SPSS (statistical package of social sciences), version 23 was utilized for both data statistical analysis and presentation measures were used:

Descriptive measures included: Count, percentage, standard deviation, minimum, and maximum.

The difference was considered significant at $p \longleftarrow 0.05$.

\section{Results}

Table (1): Reveals that age of the studied elderly ranged from 60 to up to 80 years, wih mean age 71.44 (8.00) years among the elderly people living at their homes and 69.68 (5.43) years among residents at eldry care homes. Also it was observed from the result that $59.7 \%$ and $53.3 \%$ of them respectively were females. In addition, $43.7 \%$ and $70.7 \%$ of elderly people living at their homes and residents at eldry care homes respectively were widows. Furthermore, it was shown that $25.0 \%$ and $35.9 \%$ of elderly people living at their homes and residents at eldry care homes respectively were not read and write. Concerning the elderly people' occupation before retirement; the result showed that $46.5 \%$ and $37.0 \%$ of elderly people living at their homes and residents at eldry care homes respectively were housewives. In relation to the economic status; $44.4 \%$ and $72.8 \%$ of them respec- 
tively had enough income. Also, it was revealed from the result that $50.7 \%$ and $68.5 \%$ of elderly people living at their homes and residents at eldry care homes respectively were depending on pen- sion. Regarding to elderly people living at their homes; $27.2 \%$ of them was living with their husbands or wives, while $13.7 \%$ of them lived with their sons.

Table (1): Distribution of the studied elderly according to their personal characteristics.

\begin{tabular}{|c|c|c|c|c|c|}
\hline \multirow[t]{2}{*}{ Items } & \multicolumn{2}{|c|}{$\begin{array}{l}\text { Elderly people at } \\
\text { their homes } 144\end{array}$} & \multicolumn{2}{|c|}{$\begin{array}{l}\text { Residents at eldry } \\
\text { care home } 92\end{array}$} & \multirow{2}{*}{ Significant test } \\
\hline & No. & $\%$ & No. & $\%$ & \\
\hline \multicolumn{6}{|l|}{ Age: } \\
\hline $60-<70$ & 99 & 68.8 & 79 & 85.9 & $\chi^{2}=10.685$ \\
\hline $70-<80$ & 32 & 22.2 & 12 & 13.0 & $p 0.005^{*}$ \\
\hline $80+$ & 13 & 9.0 & 1 & 1.1 & \\
\hline Mean \pm SD & & & & & $71.44 \pm 8.00$ \\
\hline \multicolumn{6}{|l|}{ Gender: } \\
\hline Males & 58 & 40.3 & 43 & 46.7 & $\chi^{2}=0.957$ \\
\hline Females & 86 & 59.7 & 49 & 53.3 & $p 0.328$ \\
\hline \multicolumn{6}{|l|}{ Marital status: } \\
\hline Single & 1 & 0.7 & 9 & 8.7 & $\chi^{2}=65.178$ \\
\hline Married & 73 & 50.7 & 2 & 3.4 & MEP $0.000 *$ \\
\hline Widow & 63 & 43.7 & 65 & 70.7 & \\
\hline Divorced & 7 & 4.9 & 16 & 17.4 & \\
\hline \multicolumn{6}{|l|}{ Education: } \\
\hline Not read and write & 36 & 25.0 & 33 & 35.9 & $\chi^{2}=23.585$ \\
\hline Read/write & 28 & 19.4 & 29 & 31.5 & MEP 0.000* \\
\hline Primary & 24 & 16.7 & 18 & 19.6 & \\
\hline Preparatory & 27 & 18.8 & 10 & 10.9 & \\
\hline Secondary & 14 & 10.0 & 2 & 2.2 & \\
\hline University & 15 & 11.1 & 0 & 0.0 & \\
\hline \multicolumn{6}{|c|}{ Occupation before retirement: } \\
\hline Employee & 38 & 26.4 & 7 & 7.6 & $\chi^{2}=6.617$ \\
\hline House wife & 67 & 46.5 & 34 & 37.0 & $p 0.158$ \\
\hline Technical workers & 20 & 13.9 & 19 & 20.7 & \\
\hline Manual workers & 7 & 4.9 & 23 & 25.0 & \\
\hline Trade business & 12 & 8.3 & 9 & 9.7 & \\
\hline \multicolumn{6}{|l|}{ Income: } \\
\hline Not enough & 29 & 20.2 & 16 & 17.4 & $\chi^{2}=22.877$ \\
\hline Enough & 64 & 44.4 & 67 & 72.8 & $p 0.000 *$ \\
\hline Enough \& save & 51 & 35.4 & 9 & 9.8 & \\
\hline \multicolumn{6}{|l|}{ \#Source of income: } \\
\hline Pension & 73 & 50.7 & 63 & 68.5 & $\chi^{2}=56.919$ \\
\hline Sons' help & 45 & 31.2 & 4 & 4.3 & MEP 0.000* \\
\hline Relatives & 2 & 1.4 & 2 & 2.2 & \\
\hline Social affairs & 5 & 3.5 & 23 & 25.0 & \\
\hline Outside work & 13 & 9.0 & 0 & 0.0 & \\
\hline Legacy & 6 & 4.2 & 0 & 0.0 & \\
\hline \multicolumn{6}{|l|}{ Living condition: } \\
\hline Alone & 28 & 20.1 & & & \\
\hline Wife/husband & 39 & 27.2 & & & \\
\hline Family & 34 & 24.5 & & & \\
\hline Son & 19 & 13.7 & & & \\
\hline Relatives & 20 & 14.4 & & & \\
\hline
\end{tabular}

* Significant at $p \leq 0.05$.

\#Means more than one answer.

$(\chi)$ Chi square for comparison of categorical variables.

(MEP)Mont Carlo Exact Probability test if the expected value of any cell was less than 5. 
Table (2): Demonstrats the length of stay in eldry care homes ranged from one year to up to 10 years with a mean was $6.07 \pm 3.29$ years; $43.5 \%$ of elders stayed at eldry care home since 7 to less than 10 years, while $5.4 \%$ of elderly people stayed form one year to less than 4 years. It also was detected from the table that $33.7 \%$ of the reasons for admission to the eldry care homes were no available house. Also, $41.3 \%$ of elderly people decided voluntarily to move there based on their own decision while $40.2 \%$ were their sons' choice. As regarded to the feeling at time of admission to the eldry care home, $55.4 \%$ and $30.4 \%$ of elderly people felt sadness and loneliness respectively, while $4.4 \%$ only of them felt happiness. Now; $67.4 \%$ and $52.2 \%$ of residents at eldry care homes were feeling loneliness and sadness respectively, while $18.4 \%$ of them now were feeling happiness. Additionally, $57.6 \%$ of elderly people were unsatisfied by their presence at geriatric homes. This was because of clashes between companions that represented $60.4 \%$.

Table (3): Shows that $57.6 \%$ and $19.6 \%$ of elderly people living at their homes and residents at eldry care homes respectively had low level of loneliness. Also, $29.2 \%$ and $45.7 \%$ of those at their homes and at eldry care homes respectively had mild level of loneliness. $13.2 \%$ and $34.8 \%$ of them respectively had high level of loneliness and this difference was statistically significant.

Table (4): Displays that the differences were statistically significant between the feeling of loneliness and age, sex, marital status, level of education, working before retirement and income respectively at $(p 0.000, p 0.025, p 0.000, p 0.000$, $p 0.045, p 0.000)$ among elderly people living at their homes. According to residents at eldry care homes, it was noticed that the differences were statistically significant between the feeling of loneliness and (sex and marital status) respectively at ( $p$ 0.001, $p$ 0.030), while the relations between feeling of loneliness and age, education, working before retirement and income were statistically insignificant.

Table (5): Illustrates that $91.6 \%$ and $89.2 \%$ of them respectively were independent in performing activities of daily living. Also, $7.0 \%$ and $5.4 \%$ of elderly people living at their homes and residents at eldry care homes respectively were dependent on others in performing activities of daily living while $1.4 \%$ and $5.4 \%$ of them needed assistance in performing activities of daily living. The statistical difference was insignificant.
Table (6): Demonstrates that $54.2 \%$ and $19.6 \%$ of elderly people living at their homes and residents at eldry care homes respectively were feeling normal level of depression, while $30.6 \%$ and $40.2 \%$ of those at their homes and at eldry care homes respectively were feeling mild level of depression. It was also noticed that $9.6 \%$ and $25.0 \%$ of them respectively were feeling moderate level of depression. While $5.6 \%$ and $15.2 \%$ of them were feeling severe level of depression. And the difference was statistically significant.

Table (2): Distribution of the studied elderly according to their admission to nursing home.

\begin{tabular}{|c|c|c|}
\hline \multirow[t]{2}{*}{ Items } & \multicolumn{2}{|c|}{$\begin{array}{l}\text { Elderly people at eldry } \\
\text { care home }(\mathrm{N}=92)\end{array}$} \\
\hline & No. & $\%$ \\
\hline \multicolumn{3}{|l|}{ Duration of stay (years): } \\
\hline $1-$ & 5 & 5.4 \\
\hline $4-$ & 39 & 42.4 \\
\hline $7-$ & 40 & 43.5 \\
\hline $10+$ & 8 & 8.7 \\
\hline \multicolumn{3}{|c|}{$\begin{array}{c}\text { Range: } 1.0-15.0 \text { years, Median }=6.0 \text { years, } \\
\text { Mean } \pm \mathrm{SD}=6.07 \pm 3.29\end{array}$} \\
\hline \multicolumn{3}{|l|}{ \#Reason for admission to eldry } \\
\hline \multicolumn{3}{|l|}{ care home: } \\
\hline - No available house & 31 & 33.7 \\
\hline - Feeling lonely & 24 & 26.1 \\
\hline - No one caring at home & 22 & 23.9 \\
\hline - Son refused to stay with him & 22 & 23.9 \\
\hline \multicolumn{3}{|l|}{ Decision of admission to eldry } \\
\hline \multicolumn{3}{|l|}{ care home: } \\
\hline - My choice & 38 & 41.3 \\
\hline - Relatives' choice & 12 & 13.1 \\
\hline - Sons' choice & 37 & 40.2 \\
\hline - Friends' suggestions & 5 & 5.4 \\
\hline \multicolumn{3}{|l|}{ \#Feeling at time of admission to } \\
\hline \multicolumn{3}{|l|}{ eldry care home: } \\
\hline - Loneliness & 28 & 30.4 \\
\hline - Sadness & 51 & 55.4 \\
\hline - Misery & 21 & 22.8 \\
\hline - Happiness & 4 & 4.4 \\
\hline \multicolumn{3}{|l|}{ \# Feeling now: } \\
\hline - Loneliness & 62 & 67.4 \\
\hline - Sadness & 48 & 52.2 \\
\hline - Misery & 15 & 16.2 \\
\hline - Happiness & 19 & 18.2 \\
\hline \multicolumn{3}{|l|}{$\begin{array}{l}\text { Satisfaction with your presence in } \\
\text { the eldry care home: }\end{array}$} \\
\hline - Yes & 39 & 42.4 \\
\hline - No & 53 & 57.6 \\
\hline \multicolumn{3}{|l|}{ Un satisfied because: (53) } \\
\hline - Clashes between companions & 32 & 60.4 \\
\hline - I want to stay in my house & 15 & 28.3 \\
\hline $\begin{array}{l}\text { - Miss-management for the geriatric } \\
\text { home }\end{array}$ & 4 & 7.5 \\
\hline - Lack of good service & 2 & 3.8 \\
\hline
\end{tabular}


Table (3): Distribution of the studied elderly according to the levels of loneliness.

\begin{tabular}{lccccc}
\hline \multirow{2}{*}{$\begin{array}{l}\text { Levels of } \\
\text { loneliness }\end{array}$} & \multicolumn{2}{c}{$\begin{array}{c}\text { Elderly at their } \\
\text { homes }(144)\end{array}$} & \multicolumn{2}{c}{$\begin{array}{c}\text { Residents at eldry } \\
\text { care home (92) }\end{array}$} \\
\cline { 2 - 6 } & No. & $\%$ & No. & $\%$ & Significant \\
\hline Low level of loneliness & 83 & 57.6 & 18 & 19.6 & $\chi^{2}=35.407$, \\
Mild level of loneliness & 42 & 29.2 & 42 & 45.7 & $p .000$ \\
High level of loneliness & 19 & 13.2 & 32 & 34.8 & \\
\hline
\end{tabular}

*Significant at $p \leq 0.05$.

$(\chi)$ Chi square for comparison of categorical variables.

Table (4): Relationship between feeling of loneliness and personal characteristics of the studied elderly.

\begin{tabular}{|c|c|c|c|c|}
\hline \multirow{3}{*}{ Items } & \multicolumn{4}{|c|}{ Feeling of loneliness } \\
\hline & \multicolumn{2}{|c|}{$\begin{array}{l}\text { Elderly people at their } \\
\text { home (144) }\end{array}$} & \multicolumn{2}{|c|}{$\begin{array}{c}\text { Residents at eldry care } \\
\text { home (92) }\end{array}$} \\
\hline & No. & Mean \pm SD & No. & Mean \pm SD \\
\hline \multicolumn{5}{|l|}{ Age: } \\
\hline $60-69$ & 99 & $41.02 \pm 13.01$ & 79 & $52.91 \pm 13.68$ \\
\hline $70-79$ & 32 & $37.94 \pm 12.15$ & 12 & $55.42 \pm 13.53$ \\
\hline $80+$ & 13 & $51.62 \pm 18.40$ & 1 & $49.00 \pm 00.00$ \\
\hline Significant test & \multicolumn{2}{|c|}{$\mathrm{F}=4.899, p 0.000^{*}$} & \multicolumn{2}{|c|}{$\mathrm{F}=0.224, p 0.800$} \\
\hline \multicolumn{5}{|l|}{ Gender: } \\
\hline Males & 58 & $37.17 \pm 12.01$ & 43 & $46.22 \pm 12.17$ \\
\hline Females & 86 & $43.40 \pm 14.48$ & 49 & $56.11 \pm 13.88$ \\
\hline Significant test & \multicolumn{2}{|c|}{$t=2.270, p 0.025^{*}$} & \multicolumn{2}{|c|}{$t=4.010, p 0.001 *$} \\
\hline \multicolumn{5}{|l|}{ Marital status: } \\
\hline Single & 1 & $59.00 \pm 00.00$ & 8 & $66.13 \pm 06.66$ \\
\hline Married & 73 & $34.29 \pm 07.82$ & 3 & $51.55 \pm 13.39$ \\
\hline Widow & 63 & $48.65 \pm 14.53$ & 65 & $58.00 \pm 16.52$ \\
\hline Divorced & 6 & $45.57 \pm 18.49$ & 16 & $52.50 \pm 13.34$ \\
\hline Significant test: & \multicolumn{2}{|c|}{$\mathrm{F}=17.784, p 0.000^{*}$} & \multicolumn{2}{|c|}{$\mathrm{F}=3.109, p 0.030^{*}$} \\
\hline \multicolumn{5}{|l|}{ Education: } \\
\hline Illiterate & 36 & $48.31 \pm 13.93$ & 29 & $53.17 \pm 15.96$ \\
\hline Read/write & 28 & $46.86 \pm 16.22$ & 18 & $53.61 \pm 10.49$ \\
\hline Primary & 24 & $37.33 \pm 10.07$ & 33 & $52.70 \pm 13.02$ \\
\hline Preparatory & 27 & $37.19 \pm 10.85$ & 10 & $54.50 \pm 14.14$ \\
\hline Secondary & 14 & $35.07 \pm 08.87$ & 2 & $51.50 \pm 17.68$ \\
\hline University & 15 & $34.31 \pm 11.46$ & 0 & - \\
\hline Significant test & \multicolumn{2}{|c|}{$\mathrm{F}=5.218, p 0.000 *$} & \multicolumn{2}{|c|}{$\mathrm{F}=0.045, p 0.996$} \\
\hline \multicolumn{5}{|l|}{ Working before retirement: } \\
\hline Employee & 38 & $37.39 \pm 12.13$ & 7 & $49.29 \pm 12.74$ \\
\hline House wife & 67 & $44.86 \pm 15.04$ & 34 & $52.06 \pm 13.08$ \\
\hline Technical Workers & 20 & $37.15 \pm 10.94$ & 19 & $52.79 \pm 14.09$ \\
\hline Manual workers & 7 & $39.14 \pm 10.96$ & 23 & $57.43 \pm 12.05$ \\
\hline Trade business & 12 & $41.83 \pm 12.70$ & 9 & $50.56 \pm 15.92$ \\
\hline Significant test & \multicolumn{2}{|c|}{$\mathrm{F}=2.501, p 0.045 *$} & \multicolumn{2}{|c|}{$\mathrm{F}=0.859, p 0.492$} \\
\hline \multicolumn{5}{|l|}{ Income: } \\
\hline Not enough & 29 & $45.55 \pm 14.74$ & 16 & $55.56 \pm 12.52$ \\
\hline Enough & 64 & $43.53 \pm 14.54$ & 67 & $53.41 \pm 14.10$ \\
\hline Enough \& save & 51 & $36.06 \pm 10.33$ & 9 & $47.33 \pm 09.46$ \\
\hline Significant test & \multicolumn{2}{|c|}{$\mathrm{F}=6.394, p 0.000 *$} & \multicolumn{2}{|c|}{$\mathrm{F}=1.106, p 0.335$} \\
\hline
\end{tabular}

*Significant at $p \leq 0.05$.

(F) One way anova for comparison of continuous quantitative variables (more than two groups).

( $t$ ) Student's test for comparison of continuous quantitative variables (two groups). 
Table (5): Distribution of the studied elderly according to the levels of ability to perform activities of daily-living (dependency level).

\begin{tabular}{|c|c|c|c|c|c|}
\hline \multirow[t]{2}{*}{$\begin{array}{l}\text { Levels of } \\
\text { dependency }\end{array}$} & \multicolumn{2}{|c|}{$\begin{array}{c}\text { Elderly people } \\
\text { at their } \\
\text { homes } \\
(144)\end{array}$} & \multicolumn{2}{|c|}{$\begin{array}{l}\text { Residents } \\
\text { at eldry } \\
\text { care home } \\
\text { (92) }\end{array}$} & \multirow[t]{2}{*}{$\begin{array}{c}\text { Significant } \\
\text { test }\end{array}$} \\
\hline & No. & $\%$ & No. & $\%$ & \\
\hline Dependent & 10 & 7.0 & 5 & 5.4 & $\xi^{2}=3.313$, \\
\hline $\begin{array}{l}\text { Independent } \\
\text { with assistant }\end{array}$ & 2 & 1.4 & 5 & 5.4 & $p 0.167$ \\
\hline Independent & 132 & 91.6 & 82 & 89.2 & \\
\hline
\end{tabular}

*Significant at $p<0.05$.

$\left(\xi^{2}\right)$ Chi square for comparison of categorical variables.

Table (7): By using a linear regression test, it was illustrated that the most important factors that significantly affected the feeling of loneliness among the elderly people living at their homes were marital status, income, health status and
Table (6): Distribution of the studied elderly according to the levels of depression.

\begin{tabular}{|c|c|c|c|c|c|}
\hline \multirow[t]{2}{*}{$\begin{array}{l}\text { Level of } \\
\text { depression }\end{array}$} & \multicolumn{2}{|c|}{$\begin{array}{c}\text { Elderly } \\
\text { people } \\
\text { at their } \\
\text { homes (144) }\end{array}$} & \multicolumn{2}{|c|}{$\begin{array}{l}\text { Residents } \\
\text { at eldry } \\
\text { care } \\
(92)\end{array}$} & \multirow[t]{2}{*}{$\begin{array}{c}\text { Significant } \\
\text { test }\end{array}$} \\
\hline & No. & $\%$ & No. & $\%$ & \\
\hline Normal & 78 & 54.2 & 18 & 19.6 & $\xi^{2}=32.028$, \\
\hline Mild depression & 44 & 30.6 & 37 & 40.2 & $p 0.000^{*}$ \\
\hline Moderate depression & 14 & 9.6 & 23 & 25.0 & \\
\hline Severe depression & 8 & 5.6 & 14 & 15.2 & \\
\hline
\end{tabular}

*Significant at $p<0.05$.

$\left(\xi^{2}\right)$ Chi square for comparison of categorical variables.

depression. Additionally, it was noticed that the most important factors that significantly affected the feeling of loneliness among the residents in eldry care homes were marital status, health status and depression.

Table (7): The most important factors affecting on the feeling of loneliness.

\begin{tabular}{|c|c|c|c|c|c|c|}
\hline & \multirow[t]{2}{*}{ Items } & \multicolumn{2}{|c|}{$\begin{array}{l}\text { Unstandardized } \\
\text { Coefficients }\end{array}$} & \multirow{2}{*}{$\begin{array}{c}\begin{array}{c}\text { Standardized } \\
\text { Coefficients }\end{array} \\
\text { Beta }\end{array}$} & \multirow[t]{2}{*}{$t$} & \multirow[t]{2}{*}{ Sig. } \\
\hline & & B & Std. Error & & & \\
\hline \multirow{11}{*}{$\begin{array}{l}\text { Elderly people living } \\
\text { at their homes }\end{array}$} & (Constant) & 42.454 & 12.118 & .067 & 3.503 & .001 \\
\hline & Age Group & 2.308 & 2.611 & $-.078-$ & .884 & .379 \\
\hline & Gender & $-2.099-$ & 2.499 & .044 & $-.840-$ & .403 \\
\hline & Marital status & 5.802 & 1.401 & .000 & $2.572-$ & $.049 *$ \\
\hline & Education & $-.002-$ & .929 & $-.131-$ & $-.002-$ & .999 \\
\hline & Work before retirement & $-1.245-$ & .890 & .554 & $-1.400-$ & .165 \\
\hline & Income & 8.084 & 1.551 & .093 & 6.054 & $.007 *$ \\
\hline & Source of income & .723 & .602 & .162 & 1.201 & .233 \\
\hline & Health Status & .984 & 1.235 & $-.120-$ & 6.796 & $.028 *$ \\
\hline & Activities of daily living groups & $-3.264-$ & 2.189 & .662 & $-1.491-$ & .140 \\
\hline & Depression & 9.237 & 1.174 & & 7.866 & $.000 *$ \\
\hline \multirow{11}{*}{$\begin{array}{l}\text { Residents at eldry } \\
\text { care home }\end{array}$} & (Constant) & 12.946 & 7.888 & & 1.641 & .103 \\
\hline & Age Group & 1.139 & 1.015 & .054 & 1.122 & .264 \\
\hline & Gender & $-1.395-$ & 1.635 & $-.050-$ & $-.853-$ & .395 \\
\hline & Marital status & 3.519 & 1.299 & .154 & 5.710 & $.008 *$ \\
\hline & Education & $-.718-$ & .490 & $-.085-$ & $-1.464-$ & .146 \\
\hline & Work before retirement & .102 & .516 & .010 & .197 & .844 \\
\hline & Income & $-.121-$ & .736 & $-.008-$ & $-.164-$ & .870 \\
\hline & Source of income & $-.114-$ & .381 & $-.015-$ & $-.299-$ & .765 \\
\hline & Health status & 1.622 & .723 & .114 & 2.242 & $.027 *$ \\
\hline & Activities of daily living groups & $-.271-$ & 1.563 & $-.010-$ & $-.173-$ & .863 \\
\hline & Depression & 11.297 & .858 & .715 & 13.171 & $.000 *$ \\
\hline
\end{tabular}

*Significant at $p<0.05$.

( $t$ ) Student's test for comparison of continuous quantitative variables (two groups).

Linear regression was applied to found the priority of factors. 


\section{Discussion}

Loneliness is upsetting feeling of social separation that occurs with the perception of inadequacy in the required figures or goodness of one's social connections. Loneliness is well reported as a prevailing problem among old people, because of life modifications and losses in aging [26,27].

The current study indicated that more than twofifths of elderly people were entered into the eldry care homes by their own decision. It was not amazing as the decision was related to the causes of joining. More than one-third of residents in eldry care homes were admitted there because there were no available houses. Moreover, more than onequarter of them felt lonely. The present results were congruent with a study carried out by Araújo, et al., in Brazil about "Differences between the profiles of institutionalized elderly people and those on waiting lists and who do not want to be institutionalized" which demonstrated that the decision of joining to the eldry care home was taken by the elderly own choice [28]. However, a study conducted by Matlabi, et al., in Tabriz, Iran about "Admission to a nursing home: Viewpoints of institutionalized older people about replacement" stated that the causes of joining to the eldry care homes were deterioration and difficulty to manage of their own homes [27]. Moreover, in a disagreement with our study Pilao, et al., mentioned that the cause of joining to the eldry care home was unemployment [29]. On the other hand, from the researcher's point of view, some elderly people expressed that the cause of admission to the eldry care home was that they did not want to be a burden on their sons and not to be a cause of marital problems to their children.

In the present study, more than half of the elderly people were unsatisfied with the presence at eldry care homes; less than two-thirds of them complain from the clashes with their companions. Furthermore, the results of the current study did not agree with the results of a study conducted by Sangar, et al., in Erbil city in Iraqi about "old age satisfaction regarding eldry care home services" that revealed that most of elderly people were satisfied with eldry care homes [30]. This may be because of the clashes among the residents made them angry and unsatisfied from the eldry care homes although they thanked the eldry care home's services. These clashes were due to the loss of their privacy and security.

These findings in agreement with Nyqvist, et al., in northern Sweden and western Finland who displayed that feeling of loneliness among residents at eldry care homes was higher than this among elderly people living at their homes because of the allocation of health and social resources were unequal [31]. This was in line with by Heidari, Ghodusi BOrujeni, and Naseh in Iran who stated that degree of loneliness among the residents at eldry care homes was higher compared to those among elderly people living at their homes [32].

The results of this study reported that above half of the elderly people living at their homes were feeling low levels of loneliness compared to less than one-fifth of those residents at eldry care homes. Furthermore, more than one-quarter of elderly people living at their homes were feeling mild levels of loneliness compared to less than one-half of residents at eldry care homes. Moreover, more than one-tenth of elderly people living at their homes were feeling high level of loneliness compared to more than one-third of residents at eldry care homes. Furthermore, this study was consistent with a study carried out in Mansoura city by Ahmed which showed that elderly people living at their homes were feeling low level of loneliness more than those at eldry care homes. Additionally, the elderly people living at their homes were feeling mild and high levels of loneliness less than the residents at eldry care homes [33].

Also, in agreement to study done at geriatric homes in Malaysia by Aung, et al., showed that three quarters of residents at eldry care homes were feeling high levels of loneliness while, there weren't mild feeling of loneliness among those residents at eldry care homes [34].

The current study illustrated that feeling of loneliness and age significantly correlated among elderly people living at their homes, while there was insignificant relation between those among residents at eldry care homes. Additionally, this result was in a line with the result of a study conducted in Canada by $\mathrm{Wu}$, and Penning regarding "Immigration and loneliness in later life" which revealed that loneliness and age significantly correlated [35]. Other findings of a study carried out in Malaysia by Aung, et al. reported that there was insignificant relation between loneliness and aging [33].

In this study, females were significantly more affected by the feeling of loneliness than males among both elderly people living at their homes and those residents at eldry care homes. This was broadly consistent with a study conducted by Teh, 
et al., in Malaysia about "Family support and loneliness among older persons" which demonstrated that old women were more vulnerable to feel loneliness than old men [36]. On the other hand, the present study was in contrast with other study accomplished by Prieto-Flores, et al., in Spain about "Family support and loneliness among older persons in multiethnic in Malaysia" which showed that women were less vulnerable to feel loneliness than men [37]. This result also contradicted with another study conducted by Singh, and Misra in Delhi in India about "Loneliness, depression, and sociability in old age" which indicated that there was insignificant relation between feeling loneliness and gender among the elderly people [38]. The results may be interpreted that the females were more frequently accessed the eldry care homes than elderly males. Furthermore, they were more susceptible to be lonely and widows than men and the loss of a spouse in elderly women was the most distressing life event they could face.

There was a significant relationship between marital status and feeling of loneliness. Single, widow and divorced (orderly) elderly people were more affected by loneliness among elderly people living at their homes and residents at eldry care homes. As well, these findings were in accordance with the findings of a study conducted by Nzabona, et al., in Uganda about "Loneliness among older persons: Examining social, economic and demographic risk factors" which showed that widow elderly people were twice liable to be lonely than elderly who were married [39]. In addition, these results supported by a study carried out by Hazer, and Boylu in Turkey about "The examination of the factors affecting the feeling of loneliness of the elderly" which illustrated that single or widowed elderly people had more feeling of loneliness than married old people [40]. Regarding the results of a study conducted by Van Tilburg, et al., in netherl ands about "Loneliness after divorce: A cohort comparison among Dutch young-old adults" it was concluded that the divorced elderly people were more liable to have feeling of loneliness than the married elderly people [41]. This result may be because of losing the intimacy relation. In addition, all residents at eldry care homes were alone either widow, divorced or single except one couple who had the permission from the government to live there and some of them were still married but they were not verbalized because of the eldry care home's restrictions and they were not known except one couple who were verbalized.

The present study reported that levels of education and feeling loneliness were significantly correlated among elderly living at their homes whereas, levels of education among residents at eldry care homes were insignificantly related to feeling of loneliness. Furthermore, the results of the present study coincided with the findings of a study stated by Asnani, et al., in Jamaica concerning "Depression and loneliness" which revealed that elderly people with lower educational levels tended to have high feeling of loneliness [42]. On the other side, the present study was in contrast with a study conducted in nine countries of the former Soviet Union by Stickley, et al., about "Loneliness: Its Correlates and Association with Health Behaviors and outcomes" which showed that the feeling of loneliness was not correlated to the educational levels [43]. This might be interpreted that the high level of education gave the chance for person to be employed with independent income, increased social networks, and participated in social events.

In the present study, loneliness and employment were significantly correlated among elderly people living at their homes, but there was insignificant relation among residents at nursing homes. Furthermore, the present study was in the same vein with Nicolaisen, and Thorsen in the United States regarding "Decreasing social isolation in older adults: Effects of an empowerment intervention offered through the care link program" reported that employment and feeling loneliness were correlated among older adults [44]. The possible explanation was that the retired elderly people felt that they lost a lot of their prestige and power after retirement and had empty times filled by loneliness.

The current findings illustrated that income was significantly correlated with the feeling of loneliness among elderly people living at their homes but there was insignificant relation among residents at eldry care homes. Similarly, the present findings agreed with a study conducted by Donovan, et al., in The United States concerning "Loneliness, depression and cognitive function in older United States adults" who found that low income was correlated with high feeling of loneliness [45] Other findings of Hazer, and Boylu in Turkey revealed that the feeling of loneliness was insignificantly correlated with level of income [40]. The rationale was that low income could affect the affordability of transportation, hindered social participation and gave the elderly people feeling that they were not accepted leading to their feeling of loneliness.

The present study indicated that there was a significant relationship between loneliness and depression. More than half of those living at their 
homes and two-fifth of residents at eldry care homes with moderate depression significantly had high feeling of loneliness, while more than onethird of elderly people living at their homes and two-fifth of residents at eldry care homes with severe depression significantly had high level of loneliness. This study was similar to a study demonstrated by Han, and Richardson in Columbia about "The relationship between depression and loneliness among homebound older persons: Does spirituality moderate this relationship?" which illustrated that feeling of loneliness and depression were significantly correlated [46]. As well, the findings of the present study agreed with the findings of a study conducted by Van Beljouw, et al. in Amsterdam about "Being all alone makes me sad": Loneliness in older adults with depressive symptoms" which found that elderly people detected with depression feeling were highly linked to feeling loneliness [41].

The current results demonstrated that there was a significant correlation between the feeling of loneliness and dependency in activities of daily living. As well, a similar study conducted by Hacihasanoglu, Yildirim, \& Karakur in Turkey regarding "Loneliness in elderly individuals, level of dependence in activities of daily living (ADL) and influential factors" showed that feeling of loneliness and dependency in activities of daily living were significantly correlated [8]. This was due to physical disability which impeded social interaction leading to loneliness.

It was illustrated from the study results that the most important factors that significantly affected the feeling of loneliness among the elderly people living at their homes were marital status, income, health status and depression. Furthermore, it was noticed that the most important factors that significantly affected the feeling of loneliness among the residents in eldry care homes were marital status, health status and depression. Additionally, a similar study conducted by Vakili, Mirzaei, \& Modarresi in Yazd in Iran concerning "Loneliness and its related factors among elderly people" showed that gender, marital status, level of education, previous job, living in eldry care home, inadequate income, feeling healthy were accompanied by loneliness [47]. On the other hand, the present study was in contrast to a study carried out by Arslantas, et al., in Tampere, Finland about "onset of loneliness in older adults: results of a 28 year prospective study" which explained that gender, marital status, level of education, having inadequate income and dependency in performing activities of daily life did not affect loneliness [48].

\section{Conclusion:}

Based on the findings of the current study, it can be concluded that residents at the eldry care homes significantly had feeling of loneliness more than elderly people living at their homes. Factors that significantly affected the feeling of loneliness among the elderly people living at their homes were marital status, income, health status and depression on the other side, factors that significantly affected the feeling of loneliness among those residents at eldry care homes were marital status, health status and depression.

\section{Recommendations:}

Based on the findings of the present study, the following recommendations are suggested:

- Encourage elderly people to participate in the social events and increase their social contacts by visiting their family members or friends.

- Give attention to the most vulnerable elderly people to prevent the feeling of loneliness like those who lost their spouses, had depressed feeling, lived at eldry care homes or depended on fulfilling their ADL.

- Help the elderly people at eldry care homes to find the causes of depression and try to solve them using the problem solving technique.

- Concentrate on the importance of keeping the elderly people in their homes using formal and informal caregivers to meet their needs and enhance their relationship with God by doing their religious rituals and going to the house of worships.

- Enhance further studies about health educational program for elderly people about coping strategies for alleviating the feeling of loneliness.

\section{References}

1- CHEN Y., HICKS A. and WHILE A.E.: Loneliness and social support of older people in China: A systematic literature review. Health \& Social Care in the Community, 22 (2): 113-123, 2014.

2- DAHLBERG L., AGAHI N. and LENNARTSSON C. Lonelier than ever? Loneliness of older people over two decades. Archives of Gerontology and Geriatrics, 75: 96103. doi:https://doi.org/10.1016/j.archger.2017.11.004, 2018.

3- LITTLE W., VYAIN S., SCARAMUZZO G., CODYRYDZEWSKI S., GRIFFITHS H., STRAYER E. and KEIRNS N.: Introduction to Sociology-1 st Canadian edition. BC Open Textbook Project, 2012.

4- World health organization: AGING, retrieved on http://www.who.int/kobe_centre/ageing/en /, 2012.

5- World health organization: Proposed working definition of an older person in africa for the mds, retrieved on 
http://www.who.int/healthinfo/survey/ageingdefnolder/en/. L. 2015.

6- LANDEIRO F., BARROWS P., MUSSON E.N., GRAY A.M. and LEAL J.: Reducing social isolation and loneliness in older people: A systematic review protocol. BMJ Open, 7 (5): e013778, 2017.

7- World Health Organization: Ageing and health, retrieved from https://www.who.int/news-room/fact-sheets/detail . lageing-and-health, 2018.

8- HACIHASANOGLU R., YILDIRIM A. and KARAKURT P.: Loneliness in elderly individuals, level of dependence in activities of daily living (ADL) and influential factors. Archives of Gerontology and Geriatrics, 54 (1): 61-66, 2012.

9- SINGH B. and KIRAN U.: Loneliness among elderly women. International Journal of Humanities and Social Science Invention, 2 (2): 10-14, 2013.

10- ENG, A.:Understanding loneliness, public health north western, retrieved on www.publichealth.northwestern. edu/docs/nphr-docs/.../nphr. 2016.

11- GERST-EMERSON K. and JAYAWARDHANA J.: Loneliness as a public health issue: The impact of loneliness on health care utilization among older adults. American Journal of Public Health, 105 (5): 1013-1019, 2015.

12- JANSSON A., MUURINEN S., SAVIKKO N., SOINI H., SUOMINEN M., KAUTIAINEN H. and PITKÄLÄ $\mathrm{K}$.: Loneliness in nursing homes and assisted living facilities: Prevalence, associated factors and prognosis. Journal of Nursing Home Research, 3: 43-49, 2017.

13- MIHAJLOVNA G.I. and RAVILEVICH A.I.: Selfregulation and experience of loneliness of elderly people who live in social care residences, International J. Sci. Env. Ed., 11 (6): 1021-1029, 2016.

14- SAITO T., KAI I. and TAKIZAWA A.: Effects of a program to prevent social isolation on loneliness, depression, and subjective well-being of older adults: A randomized trial among older migrants in Japan. Archives of Gerontology and Geriatrics, 55 (3): 539-547, 2012.

15- THEEKE L.A. and MALLOW J.: Loneliness and quality of life in chronically Ill rural older adults: Findings from a pilot study. The American Journal of Nursing, 113 (9): 28, 2013.

16- WILSON D.M., HARRIS A., HOLLIS V. and MOHANKUMAR D.: Upstream thinking and health promotion planning for older adults at risk of social isolation. International Journal of Older People Nursing, 6 (4): 282-288, 2011.

17- PHASWANA N., MAFUYA and PELTZER K.: Prevalence of Loneliness and Associated Factors among Older Adults in South Africa, Global Journal of Health Science, 12 (9): 1916-9736, 2017.

18-EBRAHEEM N., SHEHATA H. and THABET R.: Feeling of Depression and Loneliness among Elderly People Attending Geriatric Clubs, Assiut City. Life Science Journal, 9 (2): 258-321, 2012.

19- CHARAN J. and BISWAS T.: How to Calculate Sample Size for Different Study Designs in Medical Research. Indian J. Psychol. Med., 35 (2): 121-126, 2013.
20- MAHONEY I. and BARTHEL D.: Functional evaluation: The Barthel Index, Maryland State Med. Journal, 14: 5661, 1965.

21-HALLA, J. F.: Activity patterns of residents in elderly homes. Faculty of nursing, University of Alexandria, 205$214,2007$.

22- RUSSELL D.: UCLA Loneliness Scale: Reliability, validity, and factor structure. Journal of Personality Assessment, 66 (3): 20-40, 1996.

23- EL DESOKY M.M.: Loneliness scale, The Anglo Egyptian Bookshop, 1996.

24- SHEIKH J.I. and YESAVAGE J.A.: Geriatric Depression Scale (GDS). Recent evidence and development of a shorter version. In T.L. Brink (Ed.), Clinical Gerontology: A Guide to Assessment and Intervention, 165-173, 1986.

25- EL HUSSEINI S.: Effect of self care intervention on the quality of life of older adult with heart failure, faculty of nursing, University of Alexandria, 174-179, 2013.

26- COYLE C.E. and DUGAN E.: Social isolation, loneliness and health among older adults. Journal of Aging and Health, 24 (8): 1346-1363, 2012.

27- MATLABI H., HAMEDI BEHTASH H. and SHAFIEI M.: Admission to a nursing home: Viewpoints of institutionalized older people about replacement. Elderly Health Journal, 2 (1): 1-5, 2016.

28- ARAÚJO A.M., SOUSA NETO T.B. and BÓS Â.J.: Differences between the profiles of institutionalized elderly people and those on waiting lists and who do not want to be in stitutionalized. Revista Brasileira de Geriatria e Gerontologia, 19 (1): 105-118, 2016.

29- PILAO S.J., RELOJO D., TUBON G. and SUBIDA M.: Examination of factors affecting the feeling of loneliness among the elderly: Implications for intervention. Journal of Innovation in Psychology, Education and Didactics, 20 (1): 15-26, 2016.

30- SANGAR M., KAREM F., ALIREZA N. and MUAF A.: Old age satisfaction regarding geriatric home services in Erbil city. Journal of medicine and life, 8 (Spec Iss 3), 195, 2015.

31- NYQVIST F., CATTAN M. and GUSTAFSON Y.: Social resources and loneliness among the non-institutionalised and institutionalised oldest old: The GERDA studyFredrica Nyqvist. European Journal of Public Health, 23, 2013.

32- HEIDARI M., GHODUSI BORUJENI M. and NASEH L.: Comparison of self-efficacy and loneliness between community-dwelling \& institutionalized older people. Iranian Journal of Ageing, 11 (1): 142-151, 2016.

33- AHMED M.T.: Factors Affecting Loneliness Among Institutionalized and Non Institutionalized Elders, Department of Gerontology Faculty of Nursing, Mansoura University, 155-189, 2013.

34- AUNG K.T., NURUMAL M.S. and BUKHARI W.N. Loneliness among elderly in nursing home, international journal for studies on children, women, elderly and disabled, 2 (6), 2017.

35- WU Z. and PENNING M.: Immigration and loneliness in later life. Ageing \& Society, 35 (1): 64-95, 2015.

36- TEH J.K., TEY N.P. and NG S.T.: Family support and loneliness among older persons in multiethnic Malaysia. The scientific world journal, 2014. 
37- PRIETO-FLORES M.-E., FORJAZ M. J., FERNANDEZMAYORALAS G., ROJO-PEREZ F. and MARTINEZMARTIN P.: Factors associated with loneliness of noninstitutionalized and institutionalized older adults. Journal of aging and health, 23 (1): 177-194, 2011.

38- SINGH A. and MISRA N.: Loneliness, depression and sociability in old age. Industrial Psychiatry Journal, 18 (1), 51, 2009

39- NZABONA A., NTOZI J. and RUTAREMWA G.: Loneliness among older persons in Uganda: Examining social, economic and demographic risk factors. Ageing \& Society, 36 (4): 860-888, 2016.

40- HAZER O. and BOYLU A.A.: The examination of the factors affecting the feeling of loneliness of the elderly. Procedia-Social and Behavioral Sciences, 9: 2083-2089, 2010.

41- VAN TILBURG T.G., AARTSEN M.J. and VAN DER PAS S.: Loneliness after divorce: A cohort comparison among Dutch young-old adults. European Sociological Review, 31 (3): 243-252, 2014

42- ASNANI M. R., FRASER R., LEWIS N.A. and REID M.E.: Depression and loneliness in Jamaicans with sickle cell disease. BMC Psychiatry, 10 (1), 40, 2010.

43- STICKLEY A., KOYANAGI A., ROBERTS B., RICHARDSON E., ABBOTT P., TUMANOV S. and McKEE
M.: Loneliness: Its Correlates and Association with Health Behaviors and Outcomes in Nine Countries of the Former Soviet Union. PLoS ONE .8(7): e67978. doi:10.1371 /journal.pone.0067978, 2013.

44- NICOLAISEN M. and THORSEN K.: What are friends for? Friendships and loneliness over the lifespan-From 18 to 79 years. The International Journal of Aging and Human Development, 84 (2): 126-158, 2017.

45- DONOVAN N.J., WU Q., RENTZ D.M., SPERLING R.A., MARSHALL G.A. and GLYMOUR M.M.: Loneliness, depression and cognitive function in older US adults. International Journal of Geriatric Psychiatry, 32 (5): 564573,2017

46- HAN J. and RICHARDSON V.E.: The relationship between depression and loneliness among homebound older persons: Does spirituality moderate this relationship? Journal of Religion \& Spirituality in Social Work: Social Thought, 29 (3): 218-236, 2010

47- VAKILI M., MIRZAEI M. and MODARRESI M.: Loneliness and its related factors among elderly people in Yazd. Elderly Health Journal, 3 (1): 10-15, 2017.

48- ARSLANTAS H., ADANA F., ERGIN F.A., KAYAR D. and ACAR G.: Loneliness in elderly people, associated factors and its correlation with quality of life: A field study from Western Turkey. Iranian Journal of Public Health, 44 (1): 43, 2015.

\section{الشعور بالوحدة بين كبار السن المقيمين وغير المقيمين

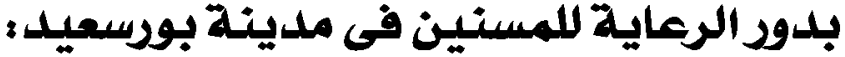 \\ دراسلة مقارنة}

$$
\begin{aligned}
& \text { يعتبر الشعقد بالوحدة بمثابة مشكلة لعدد كبير من الناس، فهناك العديد من العوامل التى تئثر على المسنين كالإنفصال عن شريك الصياة }
\end{aligned}
$$

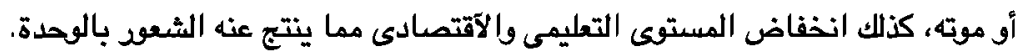

$$
\begin{aligned}
& \text { الهدف من الدراسةة: أكثشاف الثعور بالوحدة بين المسنين المقيمين وغير المقيمين بلور المسنين فى بوسعيد . } \\
& \text { تصميم البحث: تم استخدام تصميم وصفى مقارن لإجراء هذه الدراسة. } \\
& \text { حجم العينة: أجريت هذه الدراسة على جميع المقيمين بدو المعنين الحكومية بيوبسعيد وهم مبرة المسلمين لوعاية المعنين ودار المعنين }
\end{aligned}
$$

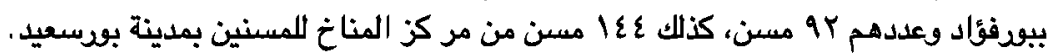

$$
\begin{aligned}
& \text { إجراءات البحث: تم جمع البيانات باستخدام استمارة مقابلة، مقياس مقَّر بارثيل، مقياس الشعقد بالوحدة (ULCA) ومقياس الأكتئاب } \\
& \text { للمسنين }
\end{aligned}
$$

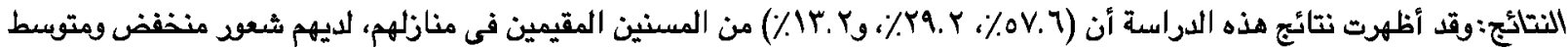

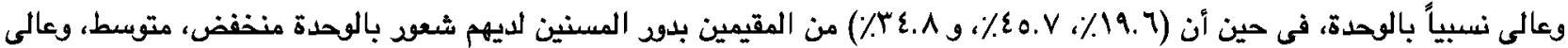

$$
\begin{aligned}
& \text { نسبياً، وهنالك فرق دال إحصائياً. }
\end{aligned}
$$

